\title{
Restoration by biomanipulation in a small hypertrophic lake: first-year results
}

\author{
E. Van Donk ${ }^{1}$, R.D. Gulati ${ }^{2}$ \& M.P. Grimm ${ }^{3}$ \\ ${ }^{1}$ Provincial Waterboard of Utrecht, Postbox 80300, 3508 TH Utrecht, The Netherlands (correspondence \\ address); ${ }^{2}$ Limnological Institute 'Vijverhof' Laboratory, Rijksstraatweg 6, 3631 AC Nieuwersluis, The \\ Netherlands; ${ }^{3}$ Organization for the Improvement of the Inland Fisheries, Postbox 433, $3430 \mathrm{AK}$ \\ Nieuwegein, The Netherlands
}

Key words: biomanipulation, lake restoration, phytoplankton, zooplankton, grazing, fish

\begin{abstract}
Biomanipulation was carried out in order to improve the water quality of the small hypertrophic Lake Zwemlust (1.5 ha; mean depth $1.5 \mathrm{~m}$ ). In March 1987 the lake was drained to facilitate the elimination of fish. Fish populations were dominated by planktivorous and benthivorous species (total stock c. $1500 \mathrm{~kg}$ ) and were collected by seine- and electro-fishing. The lake was subsequently re-stocked with 1500 northern pike fingerlings (Esox lucius L.) and a low density of adult rudd (Scardinius erythrophthalmus). The offspring of the rudd served as food for the predator pike. Stacks of Salix twigs, roots of Nuphar lutea and plantlets of Chara globularis were brought in as refuge and spawning grounds for the pike, as well as shelter for the zooplankton.

The impact of this biomanipulation on the light penetration, phytoplankton density, macrophytes, zooplankton and fish communities and on nutrient concentrations was monitored from March 1987 onwards. This paper presents the results in the first year after biomanipulation.

The abundance of phytoplankton in the first summer (1987) after this biomanipulation was very low, and consequently accompanied by increase of Secchi-disc transparency and drastic decline of chlorophyll $a$ concentration.

The submerged vegetation remained scarce, with only $5 \%$ of the bottom covered by macrophytes at the end of the season.

Zooplankters became more abundant and there was a shift from rotifers to cladocerans, comprised mainly of Daphnia and Bosmina species, the former including at least 3 species.

The offspring of the stocked rudd was present in the lake from the end of August 1987. Only $19 \%$ of the stocked pike survived the first year.

Bioassays and experiments with zooplankton community grazing showed that the grazing pressure imposed by the zooplankton community was able to keep chlorophyll $a$ concentrations and algal abundance to low levels, even in the presence of very high concentrations of inorganic $N$ and $P$. The total nutrient level increased after biomanipulation, probably due to increased release from the sediment by bioturbation, the biomass of chironomids being high.

At the end of 1987 Lake Zwemlust was still in an unstable stage. A new fish population dominated by piscivores, intended to control the planktivorous and benthivorous fish, and the submerged macrophytes did not yet stabilize.
\end{abstract}




\section{Introduction}

Most inland waters in The Netherlands suffer from a surfeit of nutrients, especially phosphorus. The increased nutrient loading has resulted in high algal biomass, and a decline or even disappearance of submerged macrophytes due to overshadowing by algae. For reducing this algal biomass various restoration techniques have been developed. In the past these included only chemical and physical manipulations like dilution, sediment dredging (Björk, 1985) and reduction of phosphorus inputs by precipitation techniques (Van Liere, 1986). However, despite some success of conventional methods, alternate restoration methods like biomanipulation have been developed (Shapiro et al., 1975).

Biomanipulation includes a series of approaches aimed at improving the 'economy' of lakes by manipulation of their trophic structure and thus the functioning of the ecosystem (Shapiro et al., 1975; Shapiro, 1980a, b; Shapiro et al., 1982; Shapiro \& Wright, 1984). These approaches are needed to overcome the high costs, delay in response and frequent inapplicability of conventional techniques. Only recently biomanipulation has been recognized as an additional restorative technique in The Netherlands (Hosper et al., 1987).

Lake eutrophication in The Netherlands is accompanied by a decline of the predatory fish pike (Esox lucius L.) because of the decrease of submerged macrophytic vegetation (Grimm, 1981). The pike requires submerged vegetation as a refuge and spawning ground. Suppression of predatory fish resulted in an increase of planktivorous and benthivorous fish biomass formed mainly of bream, Abramis brama (Lammens, 1986). Several studies have shown that planktivorous fish can cause substantial changes in the zooplankton structure (De Bernardi \& Giussani, 1975; Zaret, 1980), which in turn may affect the phytoplankton community (Shapiro et al., 1975; Andersson et al., 1978; Lynch \& Shapiro, 1981; De Bernardi et al., 1982; Lazzaro, 1987). Planktivorous fish feed on large zooplankton species and within one species the larger individuals are preferred (Hrbáček et al., 1961; Brooks \& Dodson, 1965).

Most biomanipulation experiments are based on increasing the biomass of large filter-feeding zooplankton and thus creating heavy grazing pressure on the phytoplankton. These experiments, although usually carried out in enclosures, confirm that biomanipulation is a useful technique for the rehabilitation of lakes. The technique has, however, not been widely applied (Stenson et al., 1978; Benndorf et al., 1984; Reinertsen \& Olsen, 1984; Shapiro \& Wright, 1984).

This paper describes the results of the first year after biomanipulation in the shallow, hypertrophic Lake Zwemlust at Nieuwersluis (The Netherlands).

\section{Description of the lake}

Lake Zwemlust is a small ( $1.5 \mathrm{ha})$ and shallow (mean depth, $1.5 \mathrm{~m}$; maximum depth, $2.5 \mathrm{~m}$ ) lake, located in the Province of Utrecht (Fig. 1). The lake receives nutrient-rich seepage water from the hypertrophic River Vecht, flowing some $50 \mathrm{~m}$ beside the lake; this river receives a high nutrient loading from the River Rhine, agricultural run-off and several sewage plants.

Until the mid-1960's the lake was characterized by high transparency, low algal densities and a large area covered by submerged vegetation (Le Cosquino de Bussy, 1968); for this period information on the fish population is not available. However, based on the area covered by surface vegetation, it is reasonable to assume that the population density of northern pike was high at that time (Grimm, 1983). Later the water quality deteriorated, high biomass of phytoplankton developed, submerged vegetation disappeared and the fish population structure changed when planktivores, mainly bream (Abramis brama), became dominant. At the onset of the biomanipulation vegetation-belts of Phragmites sp. were present.

The lake is important to the surrounding community because of its intensive recreational use, especially for swimming (100-3000 visitors a day). 


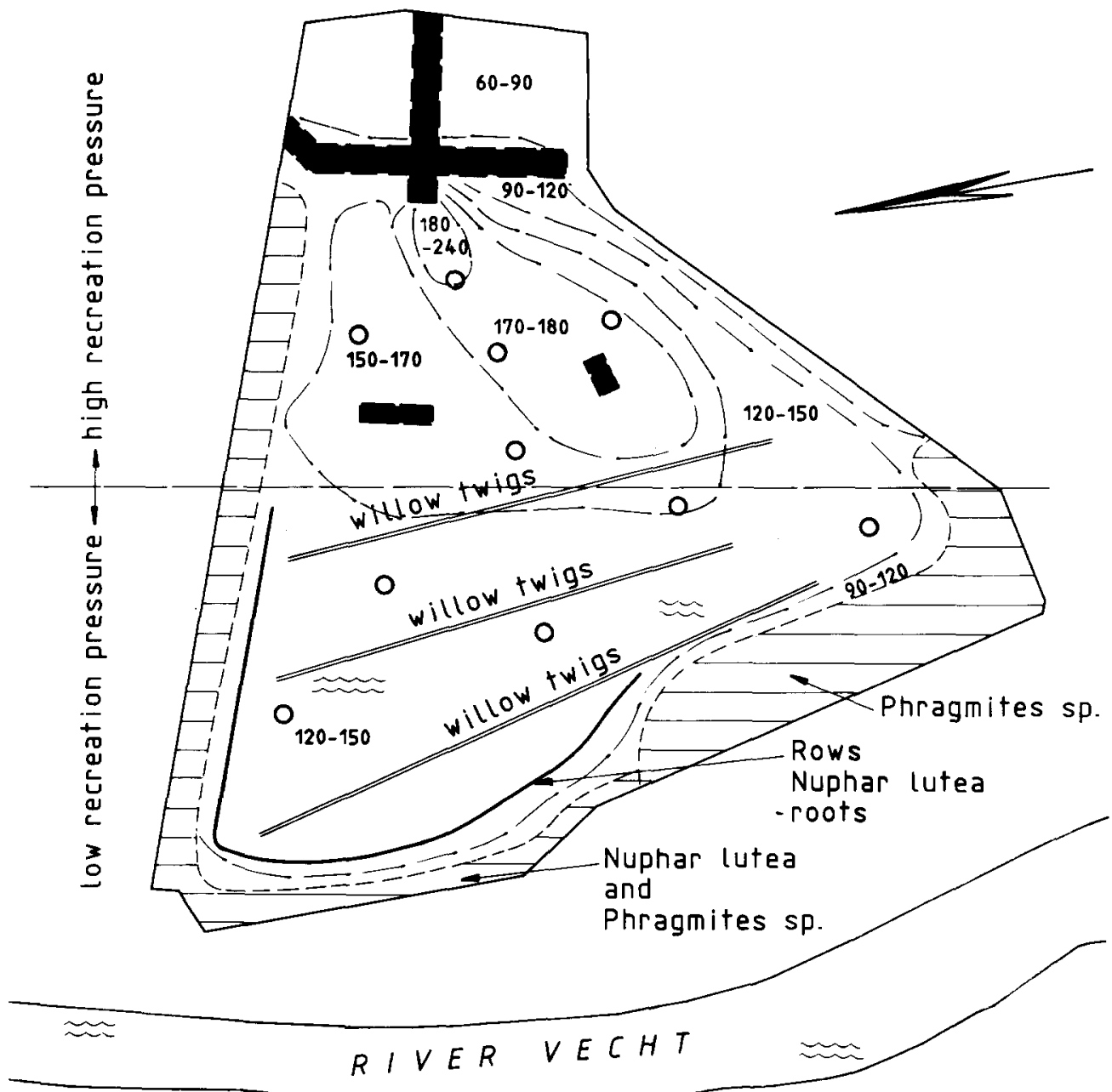

Fig. 1. Schematic map of Lake Zwemlust: sampling stations (o), arrangement of Salix (willow) twigs, marcophytes and depths (in $\mathrm{cm}$ ) are given.

Problems of water quality occurred during the summer when blooms of cyanobacteria (especially Microcystis aeruginosa) developed. Secchidisc transparency in summers before the present biomanipulation ranged from 0.1 to $0.3 \mathrm{~m}$ (Fig. 2). In The Netherlands, a Secchi-depth of $\geqslant 1 \mathrm{~m}$ is obligatory for swimming waters. In the past several restorative techniques have been attempted to reduce algal blooms in Lake Zwemlust, including dredging of the sediments and the application in 1968 of the herbicide Karmex AA $80 \%$ (diuron) (Le Cosquino de Bussy, 1968). These techniques have had no success and the algal blooms persisted.

\section{Methods}

\section{Biomanipulation operations}

During 23-26 March 1987 the lake was drained by pumping. Before that, fishes were removed, as far as possible, by seine- and electro-fishing and the rest were pumped out. On 26 and $27 \mathrm{March}$, when the lake was empty, 280 Salix-twig stacks were placed (see Fig. 1), of which 170 were fixed to the bottom and 110 remained free, so they could float after refilling the lake. In three days after the lake was emptied, seepage-water from the River Vecht refilled the lake. The Salix-twig bundles are likely 
to provide shelter for pike fingerlings and spawning grounds for the adults. Fifteen hundred fingerlings of pike $(4 \mathrm{~cm})$ were stocked at the end of April. Further, 140 adult rudd (Scardinius erythrophthalmus) were introduced so the offspring could serve as food for the pike. The lake was divided in two parts by the floating structures: in one part a high recreation pressure was allowed but in the other there was no direct recreation activity (Fig. 1). Two hundred roots of yellow lily (Nuphar lutea) and plantlets of Chara were planted near the shore (Fig. 1). The zooplankters Daphnia magna and Daphnia hyalina were also introduced (c. $1 \mathrm{~kg}$ wet weight).

\section{Sampling and sample analysis}

In 1986, i.e. before biomanipulation, samples were taken fortnightly between May and September at one station in the deepest part of the lake. In 1987 the entire water column was sampled simultaneously with a transparent, perspex tube of $1.5 \mathrm{~m}$ length and $5 \mathrm{~cm}$ diameter. The samples were taken at ten stations (see Fig. 1) and mixed. The mixed sample from these stations was subsampled for the analysis of nutrients (nitrate, nitrite, ammonium and orthophosphate), total phosphorus, chlorophyll $a$, phytoplankton and zooplankton. Temperature, conductivity, $\mathrm{pH}$, oxygen concentration and Secchi-disc transparency were measured in situ.

Methods employed for chemical analysis were according to the Dutch Standard Methods (NEN) which comply with The International Standards (ISO). The nutrients were determined by automated colorimetric methods. For chlorophyll $a$ an ethanol extraction was used.

To determine the concentration of zooplankton, 25-1 of lake water was filtered through $33 \mu \mathrm{m}$ gauze. The samples were immediately preserved in $4 \%$ formalin and subsamples were counted. To determine phytoplankton 1 litre of water was fixed with Lugol solution and the cells allowed to settle for three days. The top $900 \mathrm{ml}$ were then discarded by decanting carefully and the remaining $100 \mathrm{ml}$ were mixed. From this ten-times con- centrated sample, subsamples were taken for counting.

Fishes were caught fortnightly with a fyke-net. The fork- and total lengths were measured on live fish which were then set free. In June 1987, at 63 locations in the sediment, chironomid larvae were sampled with a perspex tube.

The growth of macrophytes was determined by monitoring monthly the composition and degree of coverage by the submerged vegetation in the lake.

\section{Bioassay experiments}

Bioassays with the phytoplankton community from the lake were carried out in June 1987 in vitro under the prevalent water temperature $\left(16^{\circ} \mathrm{C}\right)$ and light conditions (cool white fluorescent tubes at $25 \mathrm{~W} \mathrm{~m}^{-2} ; 14 \mathrm{~h}$ light-10 h dark). Eight 1-litre Pyrex flasks were filled with lake water and filtered through $100 \mu \mathrm{m}$ gauze. Two flasks were filled with unfiltered water. Five combinations (Reference (blank); $+\mathrm{PO}_{4} ;+\mathrm{NO}_{3} ;+\mathrm{NH}_{4}$; and + zooplankton) were incubated in replicates (Table 1).

The phytoplankton growth was followed for seven days by counting (Coulter Counter, $70 \mu \mathrm{m}$ orifice tube) daily the cells in subsamples. Because of the low phytoplankton concentrations, chlorophyll $a$ measurements did not appear suitable to determine the growth rate. Three size fractions of phytoplankton were distinguished: 2.8-6 $\mu \mathrm{m}$; 5.8-10.4 $\mu \mathrm{m}$ nd 10.0-28.0 $\mu \mathrm{m}$.

Table 1. Combinations in the bioassay experiments.

\begin{tabular}{llll}
\hline Combination & $\begin{array}{l}\text { Removal } \\
\text { of zooplankton }\end{array}$ & \multicolumn{2}{l}{ Nutrient addition } \\
\cline { 3 - 4 } & & $\mathrm{P}\left(\mathrm{mg} \mathrm{l}^{-1}\right)$ & $\mathrm{N}\left(\mathrm{mg} \mathrm{l}^{-1}\right)$ \\
\hline reference & + & - & - \\
$+\mathrm{PO}_{4}$ & + & 0.32 & - \\
$+\mathrm{NO}_{3}$ & + & - & 0.56 \\
$+\mathrm{NH}_{4}$ & + & - & 0.30 \\
+ zoopl. & - & - & - \\
& & & \\
\hline
\end{tabular}




\section{Zooplankton grazing and phytoplankton primary production}

The grazing and assimilation rates of the crustacean zooplankton were measured weekly in the laboratory by ${ }^{14} \mathrm{C}$-tracer technique (Gulati et al., 1982) using lake seston $(<33 \mu \mathrm{m})$ as tracer food. The biomass of seston food $(<33 \mu \mathrm{m})$ and zooplankton $(>150 \mu \mathrm{m})$ was measured by the COD technique described by Golterman (1969) and modified by Gulati et al. (1982). The oxygen consumed was converted to carbon according to Winberg et al. (1971). The expression of data in carbon units also facilitates comparison with phytoplankton primary production rates $\left({ }^{14} \mathrm{C}\right.$ technique) (Van Liere et al., 1986), which were measured only from 24 June 1987 onwards.

\section{Results}

\section{Transparency}

A marked increase of transparency occurred within 4 weeks after biomanipulation (Fig. 2). In 1986 Secchi-disc transparency in the summer was constantly low, averaging $0.3 \mathrm{~m}$ with little variation. However, a pronounced increase occurred in June-July 1987, when the Secchi-depth exceeded $2 \mathrm{~m}$ and even lake bottom was visible (Fig. 2).

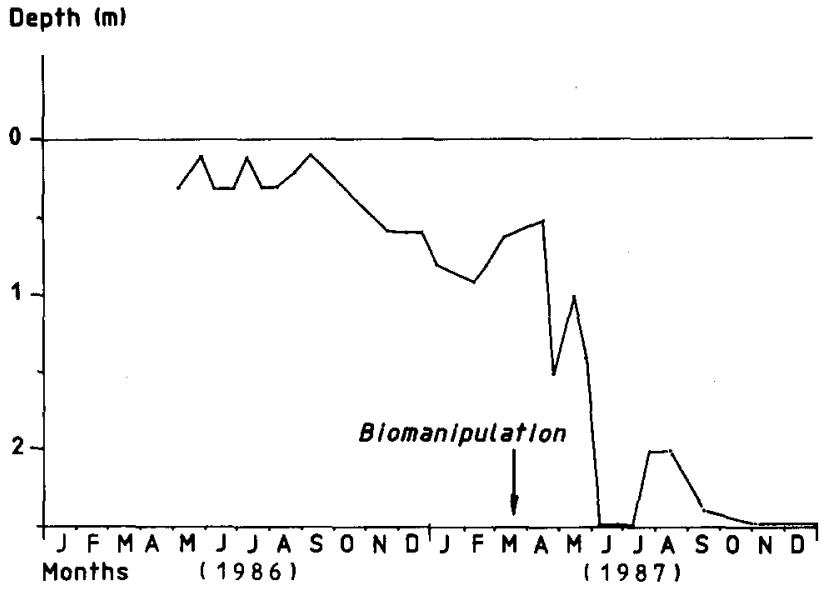

Fig. 2. Secchi-disc transparencies in Lake Zwemlust before (until mid-March 1987) and after biomanipulation.

\section{Phytoplankton}

A marked decrease was observed in chlorophyll $a$ concentration in June-July 1987 , when the low values coincided with the increase of Secchi-disc transparency. The summer concentrations in 1987 did not exceed $5 \mu \mathrm{g} \mathrm{l}^{-1}$ compared with $250 \mu \mathrm{g} \mathrm{l}^{-1}$ recorded in summer 1986 (Fig. 3).

Further, there was a change in phytoplankton species composition. In summer 1986 a bloom of cyanobacteria (Microcystis aeruginosa) was observed, but in 1987 green algae (Chlamydomonas sp., Scenedesmus sp.) and Cryptophyceae became dominant.

In 1987 no cyanobacteria were detected in the routine phytoplankton analyses.

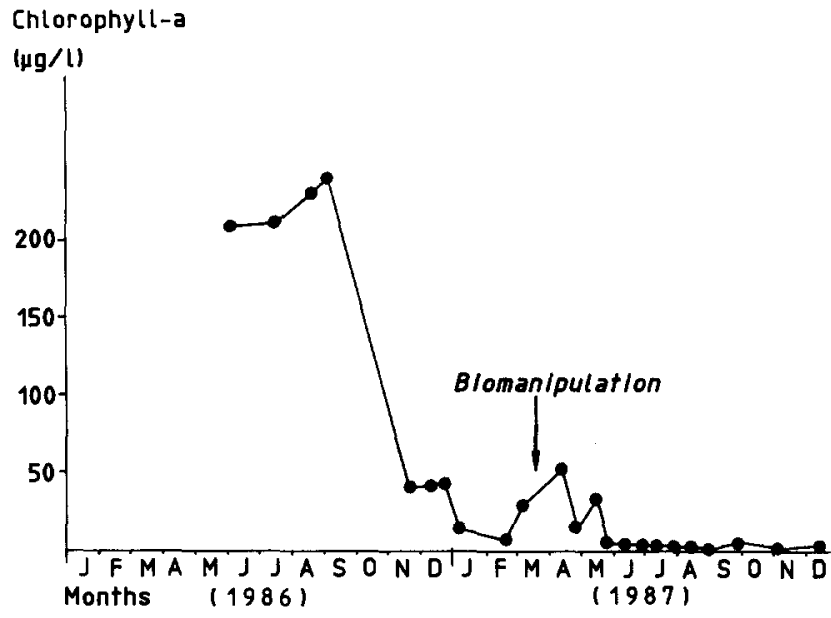

Fig. 3. Chlorophyll $a$ concentration in Lake Zwemlust before and after biomanipulation.

\section{Zooplankton}

In 1986, as in the years before, rotifers (Brachionus sp., Keratella spp., Polyarthra sp.) comprised most of the zooplankton community. At the end of April 1987, i.e. 4 weeks after biomanipulation, larger rotifers (Brachionus angularis, B. calyciflorus, Filinia longiseta, F. cornuta) were first recorded. However, only Polyarthra sp. was important throughout the summer period, being the only persistent rotifer. 
Among the crustacean zooplankters, the filterfeeding cladocerans (Fig. 4), namely Daphnia hyalina and Bosmina longirostris, became important already in mid-May 1987; i.e. about 6 weeks after the lake was filled. Daphnia magna appeared only in early July but rapidly achieved its maximum (190 ind. $1^{-1}$ ). Two other Daphnia species, $D$. cucullata and $D$. longispina, were also encountered but in relatively low densities.

The copepods were dominated by cyclopoids and their nauplii. The latter occurred in concentrations of $532-820$ ind. $1^{-1}$ in the period from early May-early July (Fig. 4).

Results from other sampling stations in the lakes, and bottom samples, show that the densities of crustacean zooplankton recorded by us in the open-water zone as described above are underestimates, particularly in case of Daphnia magna. This species tends to concentrate at the bottom and in the littoral zone during daytime and is, therefore, captured with a low efficiency using a tubesampler. This has also been confirmed in a recent preliminary diurnal study ( $E$. Slim, pers. comm.). Areal concentrations of D. magna in nocturnal samples were clearly higher than those collected during daytime.

\section{Chironomid larvae}

No data on chironomids prior to biomanipulation are available. After the biomanipulation opera-

\section{Zooplankton}

(ind/l.)

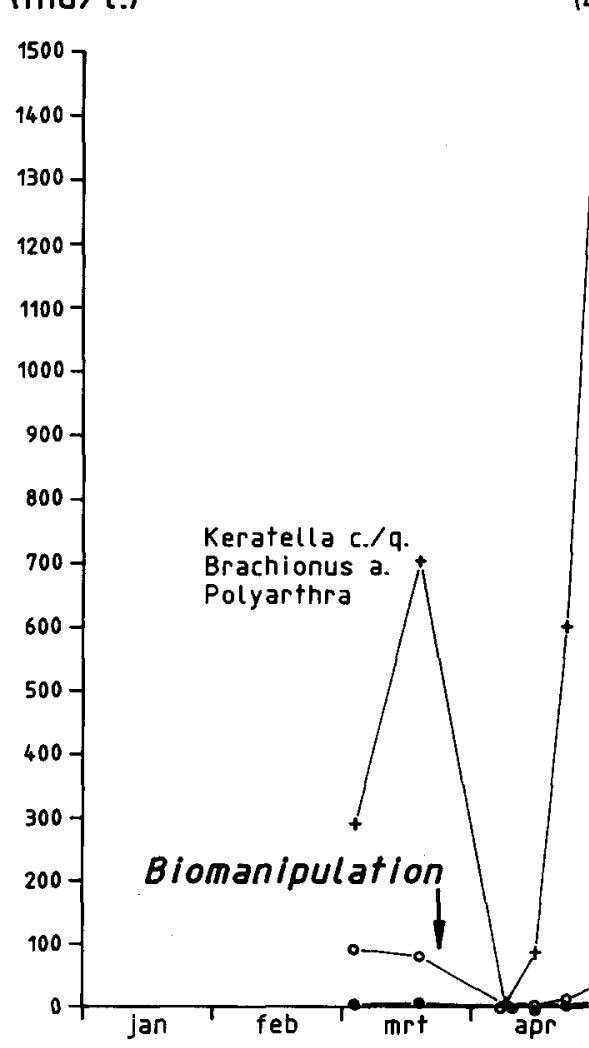

Months

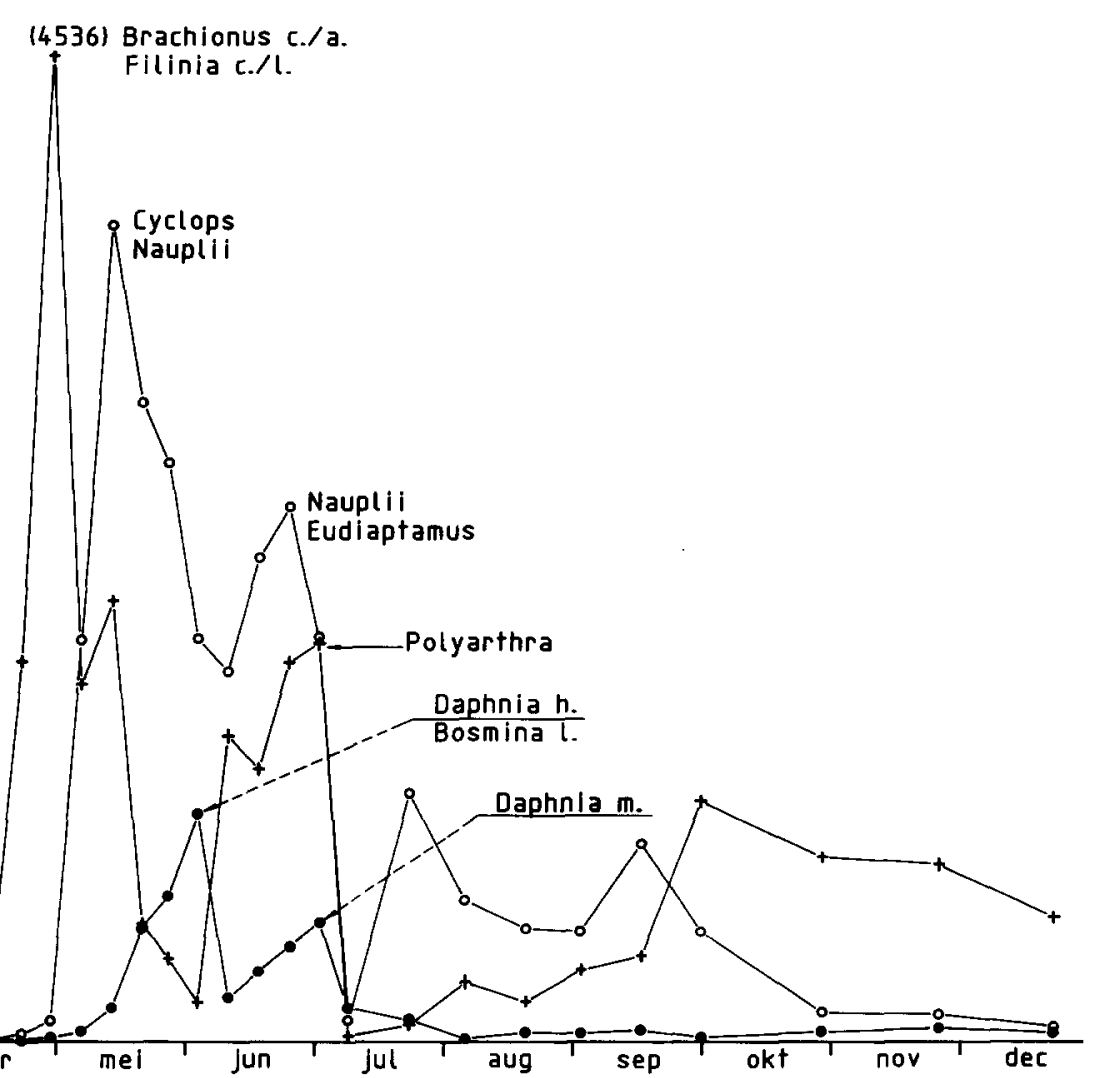

$(1987)$

Fig. 4. The change before and after biomanipulation in the abundance of herbivorous zooplankton, Rotifera ( + ), Copepoda ( 0 ) and Cladocera $(\bullet)$. The dominant species for some of the sampling dates are indicated. 
Table 2. Fish caught by seine- and electro-fishing in March 1987 (* measured by sampling).

\begin{tabular}{lcc}
\hline Species & Weight $(\mathrm{kg})$ & Number \\
\hline Bream (Abramis brama) $(>20 \mathrm{~cm})$ & 99.4 & 116 \\
(Abramis brama) $(10-20 \mathrm{~cm})$ & 435.0 & $10000^{*}$ \\
(Abramis brama) $(<10 \mathrm{~cm})$ & 50.6 & $6208^{*}$ \\
Roach (Rutilus rutilus) $(>10 \mathrm{~cm})$ & 64.0 & $4025^{*}$ \\
(Rutilus rutilus) $(\leqslant 10 \mathrm{~cm})$ & 24.7 & $2912^{*}$ \\
(Leucaspius delineatus) & 30.8 & $18547^{*}$ \\
Pike (Esox lucius) & 56.6 & 44 \\
Rudd (Scardinius erythophthalmus) $(>20 \mathrm{~cm})$ & 1.0 & 4 \\
(Scardinius erythophthalmus) $(10-20 \mathrm{~cm})$ & 5.5 & 223 \\
(Scardinius erythophthalmus) $(<10 \mathrm{~cm})$ & 0.6 & 115 \\
White Bream $($ Blicca bjoerkna) & 9.2 & 575 \\
Eel $($ Anguilla anguilla) & 15.7 & 24 \\
Tench (Tinca tinca) & 6.4 & 7 \\
Carp (Cyprinus carpio) & 6.4 & 1 \\
Perch (Perca fluciatilis) $(\geqslant 20 \mathrm{~cm})$ & 3.2 & 9 \\
(Perca fluciatilis) $(<20 \mathrm{~cm})$ & 1.7 & $357^{*}$ \\
Pike-perch (Stizostedion lucioperca) & 0.2 & 1 \\
\hline
\end{tabular}

tions the biomass of chironomids in the sediment was high (in June 1987, 8000 chironomids $\mathrm{m}^{-2}$ ), probably due to the decrease in predation by fish. More than $90 \%$ of the chironomid larvae were determined as Chironomus plumosus.

\section{Fish}

Results of the seine- and electro-fishing in March 1987 are given in Table 2. The total amount of fish removed, including those eliminated by the pumping, was estimated at $1200-1500 \mathrm{~kg}$ wet weight. The offspring of the stocked rudd were present in the lake from the end of August. Only 19\% of the stocked pike survived the first year. Despite the absence of small prey-fish during most of the year, the length-weight relation of the pike from $Z$ wemlust was similar to that of other waters. The diet of the pike consisted mainly of chironomid larvae.

\section{Macrophytes}

In 1986 there were virtually no submerged aquatic macrophytes. Of the 200 Nuphar lutea planted in 1987, 50 plants flowered. The submerged vege- tation remained scarce, only $5 \%$ of the bottom being covered by macrophytes at the end of the season. Chara globularis, Potamogeton crispus, $P$. berchtoldii and Elodea nuttallii formed most of the vegetation.

In August 1987 the macroalgae Hydrodictyon reticulatum and Enteromorpha covered up to $25 \%$ of the lake area and were emergent in the littoral zones. In 1987 plant development was probably retarded due to low summer temperature.

\section{Nutrients, oxygen and $p H$}

In 1986, the phosphorus and nitrogen concentrations in Zwemlust were very high and very similar to the values in the River Vecht from which the lake receives water by seepage (Figs. 5, 6). After biomanipulation the phosphate and ammonium concentrations even increased (Figs. 5, 6) but oxygen concentrations decreased. The higher concentration of total phosphorus probably originated from the sediments due to bioturbation by the chironomids (Gallepp et al., 1978). The $\mathrm{pH}$ declined from a maximum of 9.5 in summer 1986 to 7.7 in summer 1987 . 


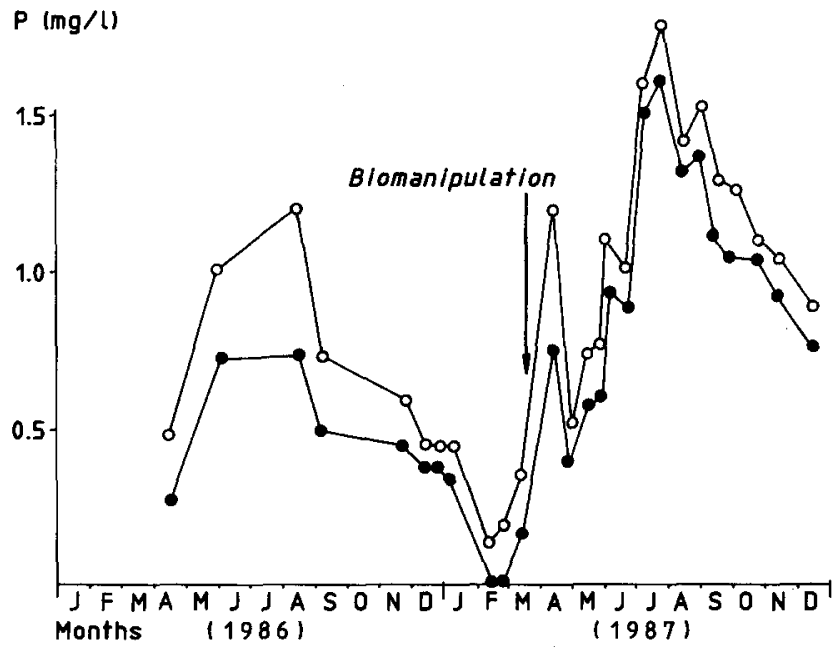

Fig. 5. The concentrations of ortho-P (•) and total-P (o) of Lake Zwemlust before and after biomanipulation.

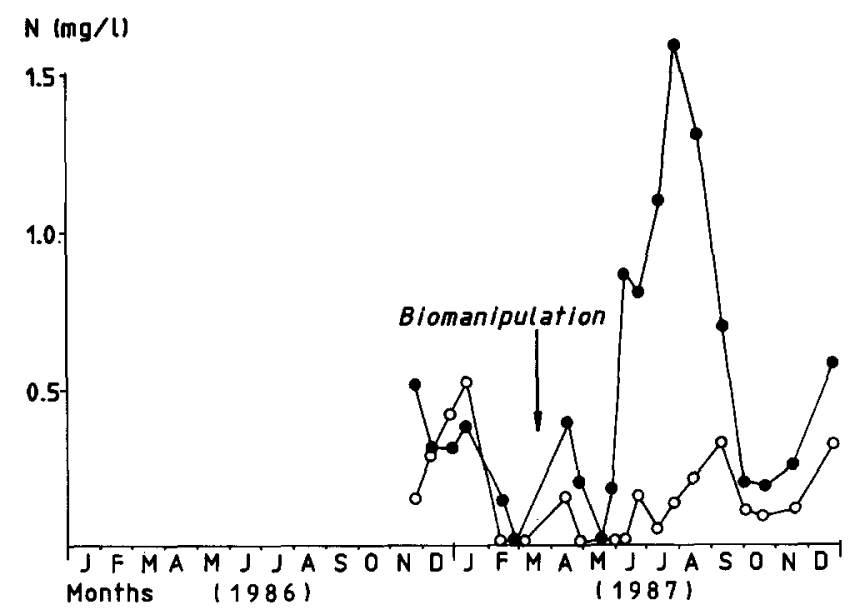

Fig. 6. The concentration of ammonium ( $\bullet$ ) and nitrate (o) of Lake Zwemlust before and after biomanipulation.

\section{Bioassay experiments}

The relative importance of nutrient limitation and increased grazing pressure was tested in the 7-day bioassay experiment. The reference (no nutrient addition, no zooplankton) and bioassays with $\mathrm{NO}_{3}, \mathrm{PO}_{4}$ or $\mathrm{NH}_{4}$ enrichment, but no zooplankton, resulted in high growth rates which did not differ within one size fraction (Fig. 7). The highest growth rates were found in the two smallest

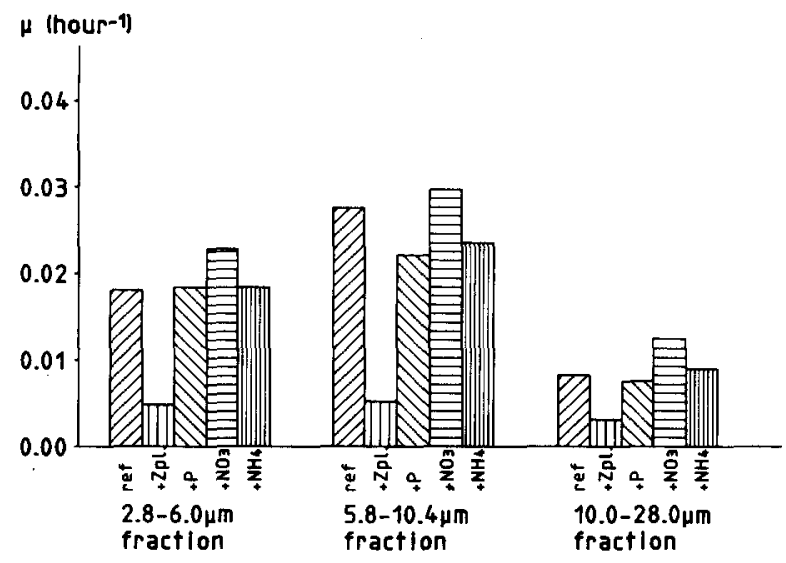

Fig. 7. Growth rates $(\mu)$ of the three phytoplankton fractions plotted for the five bioassay combinations (see text). The experiment was carried out in mid-June 1987.

fractions. In contrast, in the bioassays in which zooplankton was not removed and no nutrients were added, only a very small increase in phytoplankton numbers was observed (Fig. 7). For the size fraction of 2.8-10.4 $\mu \mathrm{m}$ the increase in numbers of phytoplankton in the different bioassays is plotted in Fig. 8. Microscopic investigation confirmed that the particles measured by the Coulter Counter were phytoplankton cells and not other organisms or detritus. The bioassays indicate that in June 1987 zooplankton grazing controlled the phytoplankton growth.

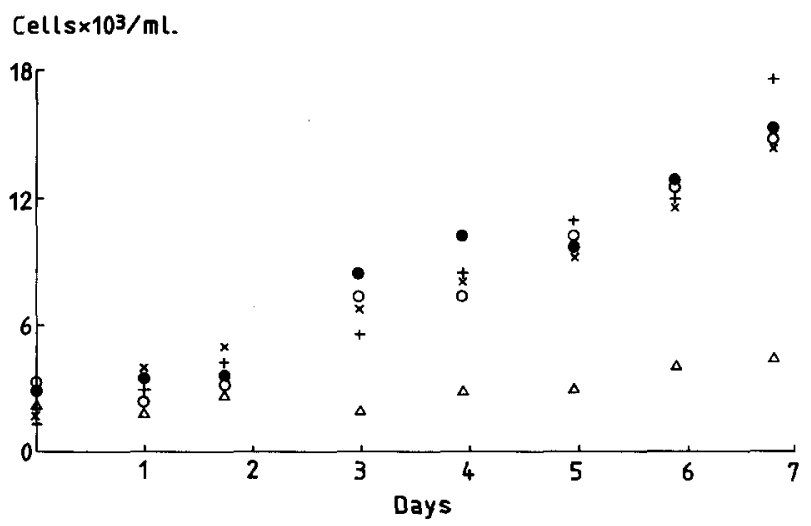

Fig. 8. Phytoplankton concentrations (size-fraction 2.8$10.4 \mu \mathrm{m}$ ) plotted against incubation time for the five bioassay combinations. Reference $\bullet$; + zooplankton, $\Delta ;+\mathbf{P}, \mathbf{X}$; + $\mathrm{NO}_{3},+;+\mathrm{NH}_{4}$, o. 
Table 3. Primary production, grazing and assimilation rates of the phytoplankton and crustacean zooplankton community and other relevant data of Lake $Z$ wemlust in 1987. The zooplankton biomass $(Z)$ and their seston food (S) are expressed as $\mathrm{mg} \mathrm{Cl}^{-1}$; the primary production (PP), consumption (C) and assimilation rates (A) are expressed as $\mathrm{mg} \mathrm{Cl}^{-1} \mathrm{~d}^{-1}$. For other codes, see footnote.

\begin{tabular}{lllllllllllr}
\hline Date & $\mathrm{T}^{\circ} \mathrm{C}$ & $\mathrm{S}$ & $\mathrm{Z}$ & $\mathrm{PP}$ & $\mathrm{SPP}$ & $\mathrm{G}$ & $\mathrm{SCR}$ & $\mathrm{C}$ & $\mathrm{A}$ & $\mathrm{A} / \mathrm{C}$ & SDA \\
\hline $15-05$ & 13 & 1.91 & 0.62 & - & - & 73 & 1.17 & 1.39 & 0.19 & 14 & 31 \\
$25-05$ & 18 & 1.28 & 1.16 & - & - & 170 & 1.47 & 2.18 & 0.95 & 44 & 82 \\
$03-06$ & 18 & 0.66 & 0.87 & - & - & 121 & 1.39 & 0.79 & 0.22 & 28 & 26 \\
$10-06$ & 17 & 0.69 & 0.56 & - & - & 195 & 3.48 & 1.35 & 0.63 & 47 & 112 \\
$17-06$ & 17 & 0.66 & 0.48 & - & - & 55 & 1.14 & 0.36 & 0.11 & 29 & 22 \\
$24-06$ & 17 & 0.62 & 0.32 & 0.35 & 62.8 & 80 & 2.50 & 0.50 & 0.21 & 43 & 67 \\
$01-07$ & 21 & 0.70 & 0.66 & - & - & 112 & 1.69 & 0.78 & 0.32 & 40 & 48 \\
$08-07$ & 24 & 0.75 & 0.34 & - & - & 65 & 1.91 & 0.49 & 0.15 & 31 & 44 \\
$22-07$ & 21 & 0.68 & 0.32 & 0.07 & 142.7 & - & - & - & - & - & - \\
$05-08$ & 18 & 0.71 & 0.20 & 0.09 & 142.2 & - & - & - & - & - & - \\
$19-08$ & 21 & 0.52 & 0.22 & 0.07 & 31.8 & 14 & 0.65 & 0.08 & 0.04 & 51 & 18 \\
$02-09$ & 20 & 0.63 & 0.30 & 0.20 & 49.0 & 46 & 1.53 & 0.29 & 0.15 & 53 & 50 \\
$16-09$ & 18 & 0.45 & 0.28 & 0.03 & 20.0 & 33 & 1.18 & 0.15 & 0.08 & 54 & 29 \\
$30-09$ & 14 & 0.25 & 0.28 & 0.04 & 56.7 & 226 & 8.08 & 0.58 & 0.19 & 33 & 68 \\
$14-10$ & 11 & 0.27 & 0.15 & 0.01 & 28.7 & 125 & 8.31 & 0.34 & 0.09 & 25 & 60 \\
$28-10$ & 10 & 0.10 & 0.16 & 0.02 & 16.0 & - & - & - & - & - & - \\
$11-11$ & 8 & 0.24 & 0.18 & 0.01 & 4.1 & 22 & 1.24 & 0.05 & 0.02 & 44 & 11 \\
$25-11$ & 6 & 0.25 & 0.23 & - & - & 24 & 1.04 & 0.06 & 0.02 & 29 & 9 \\
$22-12$ & 7 & - & - & 0.01 & 12.5 & 22 & - & - & - & - & - \\
\hline
\end{tabular}

SPP, specific primary production ( $\left.\mathrm{mg} \mathrm{C} \mathrm{mg} \mathrm{Chl}^{-1} \mathrm{~d}^{-1}\right)$; $\mathrm{G}$, grazing $\left(\% \mathrm{~d}^{-1}\right)$;

$\mathrm{SCR}$, specific clearance rate $\left(1 \mathrm{mg} \mathrm{C}^{-1} \mathrm{~d}^{-1}\right) ; \mathrm{A} / \mathrm{C}$, assimilation efficiency $(\%)$ and

SDA, specific daily assimilation $(\mathrm{A} / \mathrm{Z}$ in \%).

\section{Zooplankton grazing and phytoplankton primary production}

Results of the grazing measurements carried out between May and December 1987 are presented in Table 3. The daily zooplankton grazing (G) was often very high, with values up to $226 \%$. This is reflected in a marked reduction in seston concentration, i.e. from 1.9 to $0.1 \mathrm{mg} \mathrm{Cl}^{-1}$, the latter being one-twentieth of the spring level. The zooplankton biomass $(Z)$ to their food $(S)$ ratio $(Z / S)$, chlorophyll $a$ and Secchi transparency data all indicate the prevalence of 'oligotrophic' conditions under the high grazing pressure. The specific clearance rates (SCR) also reflect a high zooplankton filtering activity as is often found in some deep, oligo-mesotrophic Dutch lakes, with food concentrations reaching the incipient limiting level (Gulati, 1983). Both the consumption and assimilation rates of zooplankton appear to be much higher than can be supported by phyto- plankton primary production. The high grazing and assimilation activities indicate the significant role of zooplankton in improving the light climate through high seston removal. Despite the relatively low assimilation efficiencies (14-54\%), weight-specific zooplankton assimilation (SDA, Table 3) indicates generally favourable growth conditions for zooplankton dominated by larger cladocerans in the absence of planktivorous fish.

\section{Discussion}

The preliminary results of our biomanipulation experiment are comparable with those found in other similar studies in which planktivorous fish were eliminated. Larger species of herbivore zooplankton became dominant, accompanied by decline of chlorophyll $a$ concentrations and algal densities and increasing transparency (Hrbáček et al., 1961; Andersson et al., 1978; Leah et al., 
1980; Shapiro et al., 1982; De Bernardi et al., 1982; Benndorf et al., 1984; Shapiro \& Wright, 1984).

We hypothesised that decrease in algal abundance and increase in water transparency would result mainly from the sharp increase in the herbivore zooplankton populations in the absence of planktivorous fish. The bioassay and zooplankton grazing experiments support this hypothesis. The grazing pressure exerted by the crustacean zooplankton community was able to keep chlorophyll $a$ concentrations and algal abundance at very low levels, even in the presence of high concentrations of both inorganic $\mathrm{N}$ and $\mathrm{P}$ (Figs. 7, 8 and Table 3 ). The net daily grazing losses of seston appear to considerably exceed the daily primary production of phytoplankton, thus improving water clarity. Since practically all the phosphate in the lake is present as ortho-phosphate it may be assumed that algae are not P-limited, nor even light-limited because of the improved light climate.

In other lake restoration programmes a decline in nutrient concentrations was observed after removal of planktivorous fishes (Stenson et al., 1978; Henrikson et al., 1980; Shapiro \& Wright, 1984). In these lakes fishes were eliminated by rotenone. Differences in water supply (seepage in Zwemlust versus supply from the watershed) and in bioturbation by chironomids (rotenone application is known to have a negative effect on benthos: Koksvik \& Aagaard, 1984) might explain our results of nutrient enhancement.

Lake Zwemlust, however, is still in an unstable stage. A new fish population dominated by predatory fish, which will control the planktivorous fish, and a well-developed submerged vegetation, have not yet stabilized. Therefore, we placed artificial substrata and planted macrophytes as spawning grounds and refuges for the stocked pike.

In the other lakes restored by biomanipulation, all fish was removed but no measures were taken to improve the fish community by the introduction of other species and by construction of new habitats (Stenson et al., 1978; Shapiro \& Wright, 1984).
Leah et al. (1980) followed the effects of fish elimination by cormorants in Brundall Broad during one year only, and Shapiro \& Wright (1984) studied the effect of fish removal by rotenone in Round Lake for only two years. Henrikson et al. (1980) reported that the beneficial effects of fish removal lasted for at least four years, but their lake was oligotrophic and kept without fish. According to an empirical model by McQueen et al. (1986) fish removal can only be successful in oligotrophic waters. An important question concerning the use of biomanipulation as a restoration technique in the hypertrophic Lake $Z$ wemlust is the long-term effectiveness of such a measure. We intend to follow the effect of biomanipulation here for at least four years.

\section{Acknowledgements}

We thank F. Jaques and his co-workers for carrying out the biomanipulation operations. Further we thank K. Beneken Kolmer, E. Slim, P. Heuts and $\mathrm{B}$. Vlink for their work in the field and laboratory, and L. M. Matulessya for typing the manuscript.

\section{References}

Andersson, G., H. Berggren, G. Cronberg \& C. Gelin, 1978. Effect of planktivorous and benthivorous fish on organisms and water chemistry in eutrophic lakes. Hydrobiologia 59: 9-15.

Benndorf, J., H. Kneschke, K. Kossatz \& E. Penz, 1984. Manipulation of the pelagic food web by stocking with predacious fishes. Int. Revue ges. Hydrobiol. 69: 407-428.

Björk, S., 1985. Lake restoration techniques. In: Proceedings of the International congress 'Lakes Pollution and Recovery' April 1985, Rome.

Brooks, J. L. \& S. I. Dodson, 1965. Predation, body size and composition of plankton. Science 150: 28-35.

De Bernardi, R. \& G. Giussani, 1975. Population dynamics of three cladocerans of Lago Maggiore related to the predation pressure by a planktiphagous fish. Verh. int. Ver. Limnol. 19: 2906-2912.

De Bernardi, R., G. Giussani \& E. Lasso Pedretti, 1982. Select feeding of zooplankton with special reference to 
blue-green algae in enclosure experiments. Mem. Ist. Ital. Idrobiol. 40: 113-128.

Gallepp, G. W., J. F. Kitchell \& S. M. Bartel, 1978. Phosphorus release from lake sediments as affected by chironomids. Verh. int. Ver. Limnol. 20: 458-465.

Golterman, H. L., 1969. Methods for chemical analysis of freshwater. I.B.P. Handbook, No. 8. Blackwell Sci. Publ., Oxford.

Grimm, M. P., 1981. The composition of northern pike (Esox lucius L.) populations in four shallow waters in The Netherlands, with special reference to factors influencing $\mathrm{O}^{+}$pike biomass. Fish. Management 12: 61-77.

Grimm, M. P., 1983. Regulation of biomasses of small $(<41 \mathrm{~cm})$ northern pike (Esox lucius L.) with special reference to the contribution of individuals stocked as fingerlings (4-6 cm). Fish. Management 14: 115-135.

Gulati, R. D., 1983. Zooplankton and its grazing as indicators of trophic status in Dutch lakes. Envir. Monit. Assess. 3: 343-354.

Gulati, R. D., K. Siewertsen \& G. Postma, 1982. The zooplankton: its community structure, food and feeding, and role in the ecosystem of Lake Vechten. Hydrobiologia 95: 127-163.

Henrikson, L., H. G. Nyman, H. G. Oscarson \& J. A. Stenson, 1980. Trophic changes without changes in the external nutrient loading. Hydrobiologia 68: 257-263.

Hosper, S. H., M.-L. Meijer \& E. Jagtman, 1987. Biomanipulation a new perspective for restoring lakes in The Netherlands (in Dutch, English summary), $\mathrm{H}_{2} \mathrm{O}(20)$ 12: 274-279.

Hrbáček, J., M. Dvořáková, V. Kořinek \& L. Procházková, 1961. Demonstration of the effect of the fish stock on the species composition of zooplankton and the intensity of the metabolism of the whole plankton association. Verh. int. Ver. Limnol. 14: 192-195.

Koksvik, J. I. \& K. Aagaard, 1984. Effects of rotenone treatment on the benthic fauna of a small eutrophic lake. Verh. int. Ver. Limnol. 22: 658-665.

Lammens, E. H. R. R., 1986. Interactions between fishes and structure of fish communities in Dutch shallow eutrophic lakes. Thesis, University of Agriculture, Wageningen 100 p.

Lazarro, X., 1987. A review of planktivorous fishes: their evolution, feeding behaviours, selectivities, and impacts. Hydrobiologia 146: 97-167.

Leah, R. T., B. Moss \& D. E. Forrest, 1980. The role of predation in causing major changes in the limnology of a hyper-eutrophic lake. Int. Revue ges. Hydrobiol. 65: 223-247.

Le Cosquino de Bussy, L. J., 1968. Algiciden. Onderzoek over diuron als bestrijdingsmiddel van algen in de zwemvijver 'Zwemlust', Nieuwersluis, IG-TNO report, nr. A48.

Lynch, M. \& J. Shapiro, 1981. Predation, enrichment and phytoplankton community structure. Limnol. Oceanogr. 26: 86-102.

McQueen, D. J., J. R. Post \& E. L. Mills, 1986. Trophic relationships in freshwater pelagic ecosystems. Can. J. Fish. aquat. Sci. 43: 1571-1581.

Reinertsen, H. \& Y. Olson, 1984. Effects of fish elimination on the phytoplankton community of a eutrophic lake. Verh. int. Ver. Limnol. 22: 649-657.

Shapiro, J., 1980a. The need for more biology in lake restoration. In: Lake Restoration. Proceedings of a National Conference, 22-24 August 1978. U.S. Environmental Protection Agency 444/5-79-001, Minneapolis.

Shapiro, J., 1980b. The importance of trophic-level interactions to the abundance and species composition of algae in lakes. In: Hypertrophic ecosystems (Eds. J. Barica \& L. R. Mur). Junk, The Hague.

Shapiro, J., B. Forsberg, V. Lamarra, G. Lindmark, M. Lynch, E. Smeltzer \& G. Zoto, 1982. Experiments and experiences in biomanipulation: studies of ways to reduce algal abundance and eliminate bluegreens. U.S. Environmental Protection Agency EPA-600/3-82-096. Also Limnological Research Center Interim Report no. 19.

Shapiro, J., V. Lamarra \& M. Lynch, 1975. Biomanipulation: an ecosystem approach to lake restoration. In: Water quality management through biological control. (Eds. P. L. Brezonik \& J. L. Fox). Rep. no. ENV-07-75-1, University of Florida, Gainesville.

Shapiro, J. \& D. I. Wright, 1984. Lake restoration by biomanipulation: Round Lake, Minnesota, the first two years. Freshwat. Biol. 14: 371-383.

Stenson, J. A. E., T. Bohlin, L. Henrikson, B. I. Nilsson, H. G. Nyman, H. G. Oscarson \& P. Larsson, 1978. Effects of fish removal from a small lake. Verh. int. Ver. Limnol. 20: 794-801.

Van Liere, E., 1986. Loosdrecht lakes, origin, eutrophication, restoration and research programme. Hydrobiol. Bull., Amsterdam 20: 9-15.

Van Liere, E., L. van Ballegooyen, W. A. de Kloet, K. Siewertsen, P. Kouwenhoven \& T. Aldenberg, 1986. Primary production in the various parts of the Loosdrecht Lakes. Hydrobiol. Bull., Amsterdam 20: 77-85.

Winberg, G. G. et al., 1971. Symbols, units and conversion factors of freshwater productivity. IBP, London, $23 \mathrm{pp}$.

Zaret, T. M., 1980. Predation and freshwater communities. Yale University Press, New Haven and London. 187 pp. 